\title{
Multisystem dating of modern river detritus from Tajikistan and China: Implications for crustal evolution and exhumation of the Pamir
}

Barbara Carrapa ${ }^{1, *}$, Fariq Shazanee Mustapha ${ }^{1}$, Michael Cosca ${ }^{2}$, George Gehrels ${ }^{1}$, Lindsay M. Schoenbohm ${ }^{3}$, Edward R. Sobel ${ }^{4}$, Peter G. DeCelles ${ }^{1}$, Joellen Russell ${ }^{1}$, and Paul Goodman ${ }^{1}$

${ }^{1}$ Department of Geosciences, University of Arizona, Tucson, Arizona 85721, USA

${ }^{2}$ U.S. Geological Survey, Denver Federal Center, Denver, Colorado 80225, USA

${ }^{3}$ Department of Chemical and Physical Sciences, University of Toronto-Mississauga, Mississauga, Ontario L5L 1C6, Canada

${ }^{4}$ Institute of Earth and Environmental Sciences, University of Potsdam, Potsdam-Golm 14476, Germany

\section{DATA REPOSITORY}

\section{U-Pb geochronologic analyses of detrital zircon (Nu HR ICPMS)}

\section{(https://sites.google.com/a/laserchron.org/laserchron/)}

Zircon crystals are extracted from samples by traditional methods of crushing and grinding, followed by separation with a Wilfley table, heavy liquids, and a Frantz magnetic separator. Samples are processed such that all zircons are retained in the final heavy mineral fraction. A large split of these grains (generally thousands of grains) is incorporated into a 1" epoxy mount together with fragments of our Sri Lanka standard zircon. The mounts are sanded down to a depth of $\sim 20$ microns, polished, imaged, and cleaned prior to isotopic analysis. U-Pb geochronology of zircons is conducted by laser ablation multicollector inductively coupled plasma mass spectrometry (LA-MC-ICPMS) at the Arizona LaserChron Center (Gehrels et al., 2006, 2008). The analyses involve ablation of zircon with a Photon Machines Analyte G2 excimer laser (or, prior to May 2011, a New Wave UP193HE Excimer laser) using a spot diameter of 30 microns. The ablated material is carried in helium into the plasma source of a $\mathrm{Nu}$ HR ICPMS, which is equipped with a flight tube of sufficient width that $\mathrm{U}, \mathrm{Th}$, and $\mathrm{Pb}$ isotopes are measured simultaneously. All measurements are made in static mode, using Faraday detectors with $3 \times 10^{11} \mathrm{ohm}$ resistors for ${ }^{238} \mathrm{U},{ }^{232} \mathrm{Th},{ }^{208} \mathrm{~Pb}-{ }^{206} \mathrm{~Pb}$, and discrete dynode ion counters for ${ }^{204} \mathrm{~Pb}$ and ${ }^{202} \mathrm{Hg}$. Ion yields are $\sim 0.8 \mathrm{mv}$ per ppm. Each analysis consists of one 15 -second integration on peaks with the laser off (for backgrounds), 15 one-second integrations with the laser firing, and a 30 second delay to purge the previous sample and prepare for the next analysis. The ablation pit is $\sim 15$ microns in depth.

For each analysis, the errors in determining ${ }^{206} \mathrm{~Pb} /{ }^{238} \mathrm{U}$ and ${ }^{206} \mathrm{~Pb} /{ }^{204} \mathrm{~Pb}$ result in a measurement error of $\sim 1 \%-2 \%$ (at 2-sigma level) in the ${ }^{206} \mathrm{~Pb} /{ }^{238} \mathrm{U}$ age. The errors in measurement of ${ }^{206} \mathrm{~Pb} /{ }^{207} \mathrm{~Pb}$ and ${ }^{206} \mathrm{~Pb} /{ }^{204} \mathrm{~Pb}$ also result in $\sim 1 \%-2 \%$ (at 2-sigma level) uncertainty in age for grains that are $>1.0 \mathrm{Ga}$, but are substantially larger for younger grains due to low intensity of the ${ }^{207} \mathrm{~Pb}$ signal. For most analyses, the crossover in precision of ${ }^{206} \mathrm{~Pb} /{ }^{238} \mathrm{U}$ and ${ }^{206} \mathrm{~Pb} /{ }^{207} \mathrm{~Pb}$ ages occurs at $\sim 1.0 \mathrm{Ga} .{ }^{204} \mathrm{Hg}$ interference with ${ }^{204} \mathrm{~Pb}$ is accounted for measurement of ${ }^{202} \mathrm{Hg}$ during laser ablation and subtraction of ${ }^{204} \mathrm{Hg}$ according to the natural ${ }^{202} \mathrm{Hg} /{ }^{204} \mathrm{Hg}$ of 4.35 . This $\mathrm{Hg}$ is correction is not significant 
for most analyses because our Hg backgrounds are low (generally 150 cps at mass 204). Common $\mathrm{Pb}$ correction is accomplished by using the $\mathrm{Hg}$-corrected ${ }^{204} \mathrm{~Pb}$ and assuming an initial $\mathrm{Pb}$ composition from Stacey and Kramers (1975). Uncertainties of 1.5 for ${ }^{206} \mathrm{~Pb} /{ }^{204} \mathrm{~Pb}$ and 0.3 for ${ }^{207} \mathrm{~Pb} /{ }^{204} \mathrm{~Pb}$ are applied to these compositional values based on the variation in $\mathrm{Pb}$ isotopic composition in modern crystal rocks. Inter-element fractionation of $\mathrm{Pb} / \mathrm{U}$ is generally $\sim 5 \%$, whereas apparent fractionation of $\mathrm{Pb}$ isotopes is generally $<0.2 \%$. In-run analysis of fragments of a large zircon crystal (generally every fifth measurement) with known age of $563.5 \pm 3.2 \mathrm{Ma}$ (2-sigma error) is used to correct for this fractionation. The uncertainty resulting from the calibration correction is generally $1 \%-2 \%$ (2-sigma) for both ${ }^{206} \mathrm{~Pb} /{ }^{207} \mathrm{~Pb}$ and ${ }^{206} \mathrm{~Pb} /{ }^{238} \mathrm{U}$ ages. Concentrations of $\mathrm{U}$ and $\mathrm{Th}$ are calibrated relative to our Sri Lanka zircon, which contains $\sim 518$ ppm of U and 68 ppm Th. The analytical data are reported in Table DR1. Uncertainties shown in these tables are at the 1-sigma level, and include only measurement errors. Analyses that are $>20 \%$ discordant (by comparison of ${ }^{206} \mathrm{~Pb} /{ }^{238} \mathrm{U}$ and ${ }^{206} \mathrm{~Pb} /{ }^{207} \mathrm{~Pb}$ ages) or $>5 \%$ reverse discordant (in italics in Tab. DR1) are not considered further. The resulting interpreted ages are shown on probability density diagrams created using Density Plotter (Vermeesch, 2012).

\section{Hf analytical methods at the Arizona LaserChron Center}

$\mathrm{Hf}$ isotope analyses are conducted with a Nu HR ICPMS connected to a New Wave UP193HE laser (2009-2010) or a Photon Machines Analyte G2 excimer laser (2011) (Table DR2). Instrument settings are established first by analysis of $10 \mathrm{ppb}$ solutions of JMC475 and a Spex Hf solution, and then by analysis of $10 \mathrm{ppb}$ solutions containing Spex $\mathrm{Hf}, \mathrm{Yb}$, and $\mathrm{Lu}$. The mixtures range in concentration of $\mathrm{Yb}$ and $\mathrm{Lu}$, with ${ }^{176}(\mathrm{Yb}+\mathrm{Lu})$ up to $70 \%$ of the ${ }^{176} \mathrm{Hf}$. When all solutions yield ${ }^{176} \mathrm{Hf} /{ }^{177} \mathrm{Hf}$ of $\sim 0.28216$, instrument settings are optimized for laser ablation analyses and seven different standard zircons (Mud Tank, 91500, Temora, R33, FC52, Plesovice, and Sri Lanka) are analyzed. These standards are included with unknowns on the same epoxy mounts. When precision and accuracy are acceptable, unknowns are analyzed using exactly the same acquisition parameters. Laser ablation analyses are conducted with a laser beam diameter of 40 microns, with the ablation pits located on top of the U-Pb analysis pits. CL images are used to ensure that the ablation pits do not overlap multiple age domains or inclusions. Each acquisition consists of one 40-second integration on backgrounds (on peaks with no laser firing) followed by 60 one-second integrations with the laser firing. Using a typical laser fluence of $\sim 5 \mathrm{~J} / \mathrm{cm} 2$ and pulse rate of $7 \mathrm{hz}$, the ablation rate is $\sim 0.8$ microns per second. Each standard is analyzed once for every 20 unknowns.

Isotope fractionation is accounted for using the method of Woodhead et al. (2004): $\beta \mathrm{Hf}$ is determined from the measured ${ }^{179} \mathrm{Hf} /{ }^{177} \mathrm{Hf} ; \beta \mathrm{Yb}$ is determined from the measured ${ }^{173} \mathrm{Yb} /{ }^{171} \mathrm{Yb}$ (except for very low $\mathrm{Yb}$ signals); $\beta \mathrm{Lu}$ is assumed to be the same as $\beta \mathrm{Yb}$; and an exponential formula is used for fractionation correction. $\mathrm{Yb}$ and $\mathrm{Lu}$ interferences are corrected by measurement of ${ }^{176} \mathrm{Yb} /{ }^{171} \mathrm{Yb}$ and ${ }^{176} \mathrm{Lu} /{ }^{175} \mathrm{Lu}$ (respectively), as advocated by Woodhead et al. (2004). Critical isotope ratios are ${ }^{179} \mathrm{Hf} /{ }^{177} \mathrm{Hf}=0.73250$ (Patchett and Tatsumoto, 1980); ${ }^{173} \mathrm{Yb} /{ }^{171} \mathrm{Yb}=1.132338$ (Vervoort et al. 2004);

${ }^{176} \mathrm{Yb} /{ }^{171} \mathrm{Yb}=0.901691$ (Vervoort et al., 2004; Amelin and Davis, 2005); ${ }^{176} \mathrm{Lu} /{ }^{175} \mathrm{Lu}=$ 0.02653 (Patchett, 1983). All corrections are done line-by-line. For very low Yb signals, $\beta \mathrm{Hf}$ is used for fractionation of $\mathrm{Yb}$ isotopes. The corrected ${ }^{176} \mathrm{Hf} /{ }^{177} \mathrm{Hf}$ values are filtered for outliers (2-sigma filter), and the average and standard error are calculated from the 
resulting $\sim 58$ integrations. There is no capability to use only a portion of the acquired data. All solutions, standards, and unknowns analyzed during a session are reduced together. The cutoff for using $\beta \mathrm{Hf}$ versus $\beta \mathrm{Yb}$ is determined by monitoring the average offset of the standards from their known values, and the cutoff is set at the minimum offset. For most data sets, this is achieved at $\sim 6 \mathrm{mv}$ of ${ }^{171} \mathrm{Yb}$. For sessions in which the standards yield ${ }^{176} \mathrm{Hf} /{ }^{177} \mathrm{Hf}$ values that are shifted consistently from the know values, a correction factor is applied to the ${ }^{176} \mathrm{Hf} /{ }^{177} \mathrm{Hf}$ of all standards and unknowns. This correction factor, which is not necessary for most sessions, averages 1 epsilon unit. The ${ }^{176} \mathrm{Hf} /{ }^{177} \mathrm{Hf}$ at time of crystallization is calculated from measurement of present-day ${ }^{176} \mathrm{Hf} /{ }^{177} \mathrm{Hf}$ and ${ }^{176} \mathrm{Lu} /{ }^{177} \mathrm{Hf}$, using the decay constant of ${ }^{176} \mathrm{Lu}\left(\lambda=1.867 \mathrm{e}^{-11}\right)$ from Scherer et al. (2001) and Söderlund et al. (2004). No capability is provided for calculating Hf Depleted Mantle model ages because the ${ }^{176} \mathrm{Hf} /{ }^{177} \mathrm{Hf}$ and ${ }^{176} \mathrm{Lu} /{ }^{177} \mathrm{Hf}$ of the source material(s) from which the zircon crystallized is not known.

\section{REFERENCES CITED}

Amelin, Y., and Davis, W.J., 2005, Geochemical test for branching decay of 176Lu: Geochimica et Cosmochimica Acta, v. 69, p. 465-473, doi:10.1016/j.gca.2004.04.028.

Gehrels, G.E., Valencia, V., and Pullen, A., 2006, Detrital zircon geochronology by Laser-Ablation Multicollector ICPMS at the Arizona LaserChron Center, in Loszewski, T., and Huff, W., eds., Geochronology: Emerging Opportunities, Paleontology Society Short Course: Paleontology Society Papers, v. 11, 10 p.

Gehrels, G.E., Valencia, V., and Ruiz, J., 2008, Enhanced precision, accuracy, efficiency, and spatial resolution of U-Pb ages by laser ablation-multicollector-inductively coupled plasma-mass spectrometry: Geochemistry Geophysics Geosystems, v. 9, p. Q03017, doi:10.1029/2007GC001805.

Gehrels, G.E., Valencia, V., and Ruiz, J., 2008, Enhanced precision, accuracy, efficiency, and spatial resolution of $\mathrm{U}-\mathrm{Pb}$ ages by laser ablation-multicollector-inductively coupled plasma-mass spectrometry: Geochemistry Geophysics Geosystems, v. 9, p. Q03017, doi:10.1029/2007GC001805.

Patchett, P.J., 1983, Importance of the Lu-Hf isotopic system in studies of planetary chronology and chemical evolution: Geochimica et Cosmochimica Acta, v. 47, p. 81-91, doi:10.1016/0016-7037(83)90092-3.

Patchett, P.J., and Tatsumoto, M., 1980, A routine high-precision method for Lu-Hf isotope geochemistry and chronology: Contributions to Mineralogy and Petrology, v. 75, p. 263-267, doi:10.1007/BF01166766.

Scherer, E., Münker, C., and Mezger, K., 2001, Calibration of the Lutetium-Hafnium Clock: Science, v. 293, p. 683-687, doi:10.1126/science.1061372.

Söderlund, U., Patchett, P.J., Vervoort, J.D., and Isachsen, C.E., 2004, The 176Lu decay constant determined by Lu-Hf and U-Pb isotope systematics of Precambrian mafic intrusions: Earth and Planetary Science Letters, v. 219, p. 311-324, doi:10.1016/S0012-821X(04)00012-3.

Stacey, J.S., and Kramers, J.D., 1975, Approximation of terrestrial lead isotope evolution by a two-stage model: Earth and Planetary Science Letters, v. 26, p. 207-221, doi:10.1016/0012-821X(75)90088-6. 
Stacey, J.S., and Kramers, J.D., 1975, Approximation of terrestrial lead isotope evolution by a two stage model: Earth and Planetary Science Letters, v. 26, p. 207-221, doi:10.1016/0012-821X(75)90088-6.

Woodhead, J.D., Hergt, J.M., Shelley, M., Eggins, S. and Kemp, 2004, R. Zircon Hfisotope analysis with an excimer laser, depth profiling, ablation of complex geometries, and concomitant age estimation: Chemical Geology, v. 209, p. 121-135.

Vermeesch, P., 2012, On the visualisation of detrital age distributions: Chemical Geology, v. 312-313, p. 190-194, doi:10.1016/j.chemgeo.2012.04.021.

Vervoort, J.D., Patchett, P.J., Söderlund, U. and Baker, M., 2004, The isotopic composition of $\mathrm{Yb}$ and the precise and accurate determination of $\mathrm{Lu}$ concentrations and $\mathrm{Lu} / \mathrm{Hf}$ ratios by isotope dilution using MC-ICPMS: Geochem Geophys Geosyst. doi:2004GC000721RR. 